NBER WORKING PAPER SERIES

A CONSTANT RECONTRACTING

MODEL OF SOVEREIGN DEBT

Jeremy I. Bulow

Kenneth Rogoff

Working Paper No. 2088

NATIONAL BUREAU OF ECONOMIC RESEARCH

1050 Massachusetts Avenue

Cambridge, MA 02138

December 1986

The research reported here is part of the NBER's research program in International Studies. Any opinions expressed are those of the authors and not those of the National Bureau of Economic Research. 
NBER Working Paper \#2088

December 1986

A Constant Recontracting Model of Sovereign Debt

\begin{abstract}
Few sovereign debtors have repudiated their obligations entirely. But despite the significant sanctions at the disposal of lenders, many borrowers have been able to consistently negotiate for reduced repayments. This paper presents a model of the on-going bargaining process that determines repayment levels.

We derive a bargaining equilibrium in which countries with large debts achieve negotiated partial default. The ability to credibly threaten more draconian penalties in the event of repudiation may be of no benefit to lenders. Furthermore, unanticipated increases in world interest rates may actually help the borrowers by making lenders more impatient for a negotiated settlement. Finally, Western governments may be induced to make payments to facilitate reschedulings even though efficient agreements will be reached without their intervention.
\end{abstract}

Jeremy Bulow

Graduate School of Business

University of Chicago

1101 East 58th Street

Chicago, Illinois 60637

(312) 962-7137
Kenneth Rogoff

Department of Economics University of Wisconsin 1180 Observatory Drive Madison, Wisconsin 53706 (608) 263-3876 


\section{A Constant Recontracting Model of Sovereign Debt}

\section{Introduction}

Over the past several years, a large number of less-developed countries have repeatedly "rescheduled" their payments on loans from Western banks. ${ }^{1}$ These reschedulings have typically involved only a postponement of payments (with interest) rather than outright repudiation, but many observers are skeptical whether the loans will ever be repaid in full. In the (limited) secondary market for LDC loans, bank loans to many countries particularly South American debtors - trade at substantial discounts. ${ }^{2}$ There is also evidence that anticipated LDC loan losses are reflected in the stock market values of major creditor banks. ${ }^{3}$ Given that the net external liabilities of all developing countries stood at over 950 billion dollars by the end of $1985^{4}$, it is not surprising that the "LDC debt crisis" has attracted a great deal of attention. (The Appendix presents figures for some of the major individual borrowers.)

An essential feature of sovereign lending is that creditors have only indirect means to enforce repayment. As a consequence, countries may choose to default long before the stage is reached where they are literally unable to pay. Economists have made substantial progress towards understanding the special problems of sovereign lending ${ }^{5}$ but still, the current generation of models have some fundamental limitations. The most important limitation is thay they fail to provide a satisfactory theory explaining partial default. The

1 In 1983, 18 countries rescheduled the payments on 61 billion dollars of debt. In 1984, 19 countries rescheduled 136 billion dollars and in 1985, 14 countries rescheduled 51 billion dollars. From 1980 - 1982, there were an average of six reschedulings per year. See Watson et al (1986), Tables 36,37 and 38 .

2 See "Latin American Loans: Selling Them for All They're Worth," in the Economist, March 2, 1985, "U.S. Banks Swap Latin Debt," in the New York Times, September 11, 1986 and "Growing Market in Third World Debt Raises Questions on the Loans' Value," in the Wall Street Journal, October 7, 1986. According to the Wall Street Journal report, estimates of the market for 1986 are on the order of four hundred million dollars per month. That article cites lists published by Salamon Brothers and Merrill Lynch as the source for the following table of offer prices (cents per dollar of direct government loans): Argentina, 67; Brazil,76; Chile, 69; Ecuador, 66; Mexico, 62; Nigeria, 60; Peru, 24; Phillipines, 62; Poland, 53; and Venezuela, 77. Bid prices are two to five cents below offer prices.

3 See Kyle and Sachs (1984).

- See World Bank Debt Tables.

5 Eaton, Gersovitz and Stiglitz (1986) provide an overview of the literature. See also the other articles in the June 1986 edition of the European Economic Review, as well as the papers in Cuddington and Smith (1985). 
experience of the past decade strongly suggests that reschedulings are negotiated partial defaults; countries can and do bargain down their repayments without necessarily refusing to pay entirely. Moreover, rescheduling appears to be a process of constant rebargaining rather than a one-time partial repudiation of debt.

The purpose of this paper is to develop a simple but more realistic model of sovereign default, one which explains negotiated partial defaults and repeated reschedulings. ${ }^{6}$ According to our model, if banks thought that the increased integration of trade after World War II would make complete default prohibitively costly for an LDC, they might well have been right. If debtor countries had to choose between paying off their debts and facing trade and financial autarky, they might well choose to pay off their loans on a timely basis. But unfortunately (ex post) for the banks, they cannot restrict a debtor country to these two options by making "take it or leave it" offers. When the country is more realistically treated as being able to make counteroffers, the banks cannot always credibly refuse to bargain.

The maximum level of borrowing a debtor country can undertake (henceforth we refer to the LDC borrower as the "country") depends on the probability distribution of its output, its terms of trade, and world interest rates. Unanticipated movements in these variables can lead to reschedulings and, because partial default is possible, the level of repayments is continuous in the realizations of the disturbances. ${ }^{7}$ One interesting prediction of the model is that an unanticipated rise in world interest rates can actually reduce a country's repayments to the banks. Higher world interest rates hurt banks' bargaining position since they become more anxious to get their money out of the LDC and into high yielding investments elsewhere. A debtor country can exploit this impatience in rescheduling negotiations.

Our bargaining approach extends naturally to exploring the role of Western governments (henceforth the "U.S.") in the rescheduling process. A key point here is that the U.S. may be better off if it can precommit not to participate in rescheduling negotiations, even if U.S. consumers have a significant vested interest in keeping up the level of trade,

6 The closest antecedent to our paper would appear to be Ozler (1984). Ozler recognizes that bargaining may occur in place of repudiation, because bargaining leads to more efficient outcomes. Her model, however, does not incorporate a strategic model of the bargaining process.

7 The fact that in our model repayments are continuous in the disturbances would seem to make it more directly applicable to time series data than "all or nothing" default models. 
and even if the loans have already been made. ${ }^{8}$ Unfortunately, in a perfect equilibrium, the U.S. may not be able to avoid making sidepayments. The banks and the country can exploit its impatience for trade to resume.

In Section II we develop the basic model, in which the only collateral for sovereign lending is the country's gains from trade. In Section III, we derive the equilibrium lending contract, and show that it must be enforceable as a bargaining equilibrium at each instant in time. Even if one increased banks' power to punish the country in the event of default, banks still might not be able to collect higher repayments when there is bargaining. The model of Sections II and III is nonstochastic, so there are never actually any defaults, partial or otherwise. In Section IV, we allow for uncertainty in output and world interest rates. It is in this section that we show why an unanticipated rise in world interest rates may actually make the debtor country better off. Even with uncertainty, there still needn't be any formal reschedulings if the explicit legal contract between the banks and the country is fully state contingent and can be supported at all times as a bargaining equilibrium. However, at the end of Section IV, we discuss reasons why the legal contract might differ from the implicit contract, and hence why the need for reschedulings can arise. In Section V, we introduce the U.S. into the analysis, and in Section VI we indicate how to interpret our results when either the banks and/or the country's political parties do not act as a single monolithic bargainers. In the conclusions, we discuss some of the empirical observations which motivated our choice of modeling strategies. One issue is whether a country's main incentive to repay its debts is to protect its rights to trade freely, or whether it is the desire to have the option of borrowing again in the future.

\section{Tastes, Technology, and the Legal Environment}

We begin by stating the optimization problem of the country. To do so requires specifying the country's objective function, describing its production technology, its trading and borrowing possibilities, and the legal environment in which it operates. Later in this section, we will describe the optimization problem of the banks in an analogous fashion.

8 Earlier authors have suggested that the U.S. may be forced to "bail out" the banks because of commitments through Federal Deposit Insurance [see Folkerts-Landau (1985)]. In our model, the U.S. is concerned with gains from trade. 
The country is governed by leaders who seek to maximize the objective function

$$
\Lambda_{t}=\sum_{i=0}^{\infty}\left(C_{t+h i}^{D}+C_{t+h i}^{F}\right) /(1+\delta h)^{i}, \quad 0<\delta
$$

where $C^{D}$ and $C^{F}$ are domestic consumption of good $D$ and good $F$ respectively, $h$ is the length of a time period, and $\delta h$ is the leaders' rate of time preference (per period). ${ }^{9}$ Throughout most of our discussion, there will be no presumption that the country's leaders' preferences coincide with those of its citizens. In fact, we will assume that the leaders' objective function discounts the future at a rate above the world interest rate, regardless of investment opportunities and consumer preferences. The rationale is that the leaders are uncertain about the length of their tenure in office, or alternatively, their life expectancy.

Production is exogenous. Each period the country produces $\bar{y} h$ units of good $D$. This output can be consumed domestically, stored (in storage the good shrinks by $100 \gamma h$ percent per period), or traded internationally in exchange for good $F$. If traded, each unit of good $D$ fetches $P$ units of good $F, P>1$. Since the two goods are perfect substitutes in the leaders' utility function, it is clear that with free trade, all production of $D$ will be exchanged for units of $F$.

The country's ability to trade freely is compromised whenever it is in default on its foreign debt. Although foreign creditors have no means to seize assets within the country itself, their claims do have standing in U.S. courts. This makes the country's ships, goods in transit, and asset holdings subject to seizure in U.S. territory. Creditor banks can also interfere with the country's access to trade credits, and this interference will make it quite difficult for the country to conduct non-barter trade. We are implicitly assuming that when a country borrows money it will sign a contract, valid in U.S. courts, which grants creditor banks these rights of seizure. Later, in Section IV, we discuss why it will always be in the interests of the country to sign such a contract.

We model the seizure technology by assuming that whenever the country trades while in default, the banks are able to seize up to $100 \beta$ percent of the goods in transit, $0<\beta<1$. Since the banks may incur costs of seizure, their net benefit is only a fraction $\alpha, 0<\alpha \leq \beta$,

9 By restricting our attention to the case where the country's leaders are risk neutral, we are able to simplify our analysis of rescheduling agreements considerably. 
of the quantity of the country's trade subjected to seizure. ${ }^{10}$ The country's optimization problem (sans perfection constraints) is thus given by:

$$
\max _{T, R, S} \Lambda_{t}=\sum_{i=0}^{\infty}\left(C_{t+h i}^{D}+C_{t+h i}^{F}\right) /(1+\delta h)^{i}, \quad 0<\delta,
$$

subject to

$$
\begin{gathered}
S_{t+h}=(1-\gamma h) S_{t}+\bar{y} h-C_{t}^{D}-T_{t}, \\
C_{t}^{F}=T_{t} P\left(1-\beta X_{t}\right)-R_{t}
\end{gathered}
$$

where $S_{t}$ is the beginning-of-period- $t$ stock of good $D, T_{t}$ is the quantity of good $D$ exported in period $t$, and $R_{t}$ represents payments by the country to foreign banks (in units of good $F) . X_{t} \in[0,1]$ is the percent of the country's shipments which the banks attempt to seize. When the country is in technical default, $X$ is a choice variable of the banks. The country is also subject to two other types of constraints. First, the country must provide the banks with at least zero economic profits, a condition we will make precise after formalizing the banks' optimization problem. Second, because of the country's inability to commit to future repayments, it faces certain perfection constraints on its actions. The mathematical implications of these constraints will be analyzed in section III.

To rule out supergame (reputational) equilibria in the later analysis, we assume that the country can only produce good $D$ until some known future date $t^{*}$, after which its output is limited to $\bar{y} h$ units of good $F$ per period; $t^{*}$ can be arbitrarily large.

We now turn to the optimization problem of the banks. The country can borrow abroad from competitive, risk-neutral banking consortiums. However, no consortium will lend the country funds at the world interest rate unless the loan contract includes a clause (which as always, will be enforceable only in U.S. courts), which gives the consortium seniority

10 Obviously, in a more general setting the country will redirect trade and investment so as to minimize its losses from seizure. The operative assumption here is that the country would be better off if it did not have to take such measures. 
over future lenders. A sufficiently strong clause would be one which says that the country cannot borrow elsewhere beyond a pre-specified limit without permission of all its creditors; abrogation of this clause causes the consortium's debt to be due and payable immediately. The contract also must assign the consortium a senior claim over later creditors in dividing up any seizures; this clause insures that the initial consortium will have enough bargaining power to obtain at least as high a rate of return as any future lenders brought in by the country in violation of its borrowing-limit clause. However, the contract will not give the banks in the initial consortium any ex post monopoly power over the country as long as the country is always allowed to repay its outstanding loans by replacing them with loans from a new competitive consortium. ${ }^{11}$

We assume that with the help of cross-default clauses, each banking group is able to negotiate with the country as a unified entity. In Section VI, we relax this assumption and show that it is not essential for the results below.

The world one-period interest rate is $r_{s} h$ in period s. In the nonstochastic model of the next two sections $r_{s}=r$, a constant. A bank consortium will only agree to make a loan with repayment schedule $\left\{R_{t}\right\}$ if

$$
\max _{X} \sum_{i=0}^{\infty}\left(R_{t+h i}+\alpha T_{t+h i} X_{t+h i}\right) /(1+r h)^{i} \geq 0
$$

where the repayment $R$ is negative in periods when the banks are giving cash to the country. $X$ represents the percent of the country's shipments which the banks subject to seizure. If the country is not in arrears, then $X$ is legally constrained to zero. If the country is in default on its debt, banks can legally subject up to 100 percent of the country's shipments to seizure $(X=1)$, unless setting $X$ at a lower level is sufficient to cover the country's obligations. Because the seizure technology exhibits constant returns to scale, the banks will always set $X$ at its legal maximum in any given period, in which case they recoup $X \alpha T$.

11 Basically, we need covenants enforceable in U.S. courts that prevent the country and a second group of banks from being able to jointly game the initial consortium. The country will not be able to induce a second bank consortium to come in unless the second consortium expects to get at least a market return. As long as the initial consortium's bond covenents are strong enough to give it seniority in any default proceedings, the new lenders will be unable to make a sufficient rate of return unless the old lenders are paid the market rate. See Brau and Williams (1983) for a further discussion of interlender equity issues in resched uling. 
Note that the banks' threat to harass the country's trade if it defaults is credible; they gain positive profits and do not sacrifice future negotiating leverage. We are now ready to solve for the equilibrium in our model.

\section{The Equilibrium Loan Contract}

If the country's leaders could maximize (1) subject only to (2)-(5) and an in tegral budget constraint, they would arrange to borrow the entire present value of future output for immediate consumption so long as $\delta>r .{ }^{12}$ However, the banks will not be willing to lend the country more than it can be forced to repay. The only credible threat that the banks have against the country is to harass its trade and therefore, loans will be limited by the effectiveness of this threat.

It is useful to proceed by asking how much creditor banks can collect if the country owes them an infinite amount of debt. In this case the country will never be able to trade freely without a rescheduling agreement with the banks. Obviously the country will never pay more for a rescheduling agreement than it would lose through seizure. However, even if the country owes banks an infinite amount, they may not be able to get all the country's gains from trading. Through bargaining, the country may be able to force the banks to settle for lower payments.

If bargaining is limited to the banks' making take-it-or-leave-it offers to the country over repayments, then the banks can indeed extract the full amount of the country's costs of seizure. This is easily shown to be true even though the country has the ability to refuse such an offer and store any output of good $D$ for future sale or consumption. If, however, rescheduling negotiations are more realistically viewed as bilateral, repayments can be less. Following Rubinstein (1982), we will employ an alternating offers model of bargaining as a way of modeling negotiations. ${ }^{13}$

12 In a more general setting in which the country's leaders are risk averse, they will want to borrow enough to equate the ratio of present discounted marginal utilities of consumption between any two periods with the world interest rate. If, however, their ability to commit to repayments is limited, they may have to shift consumption into future periods; see for example, Sachs (1984). This case is in most respects qualitatively equivalent to the model of the text. The most significant difference is that in the risk-averse case, the country might take time to run up its debt instead of doing it all at once.

13 The problem here differs in some respects from Rubinstein's. In this model, the players are engaged in repeated bargaining over a sequence of goods, each of which produce a one- 
Before further characterizing the bargaining process, it is useful to note two special features of our model. First, it is never efficient to have the country pay out more than is necessary to clear the way for trading current output (and any cumulated stock). In particular, the country will not pay the banks a lump-sum amount in exchange for contractual permission to trade freely for longer than just the current period. Such a payment is never part of an equilibrium bargain, because it is inefficient for the high discount rate country to make advance payments to the low discount rate banks. Second, we can think of the banks and the country as bargaining separately over each unit of output. Because both sides are risk neutral, the gains from trade will be split in the same proportion regardless of the level of inventory held by the country (that is, regardless of the quantity of output being bargained over). ${ }^{14}$

To close the model, it is still necessary to specify the exact nature of the bargaining process. We will assume that the country and the banks take turns making offers with respect to the output produced in a given period. The length of time between offers is the same as the length of time between periods, $h$. The banks always get to make the first offer, though this advantage is of little consequence if the length of time between periods is very small, as we shall assume.

Our notation for describing the bargaining process is as follows: If the output being negotiated was produced in period $t$, then the banks' offer in period $t+s$ is characterized by $q(t, s)$, where $q$ is the fraction of remaining output (initial period t output less depreciation) going to the banks and $1-q$ is the fraction that goes to the country. When it is the country's turn to make an offer, it proposes a division $q^{\prime}(t, s)$, whereby the banks get $q^{\prime}$ of output, and the country gets $1-q^{\prime}$. When a rescheduling agreement is reached, the banks receive a payment from the country and in return contract to not interfere in the trade of goods

time benefit to the consumer. Rubinstein analyzes a bargain over a good that produces a flow of services to its owner. While in the flow model the current owner of a good is able to enjoy services in any interval prior to sale, in the stock model the owner's bargaining power may be diminished by his inability to do any consuming prior to concluding a trade agreement.

14 With varying risk tolerances the problem becomes more complex, because the more risk averse party (technically, the party with the lower ratio of marginal utility of income to the average marginal utility of income over the amount of income attained in the equilibrium bargain) will be at a disadvantage in bargaining over relatively large amounts. For more on bargaining under risk aversion, see Roth (1984). 
produced in period $t$.

We will impose that the equilibrium be a perfect equilibrium. Roughly speaking, in a perfect equilibrium neither side can influence the bargaining by trying to make a threat (such as "take this offer or I'll walk") which it would not carry out if called upon to do so. Formally, in every subgame of a perfect equilibrium, the strategies used by each of the players must form a Nash equilibrium. In a perfect equilibrium, either party (i.e., the bank or the country) will agree to a rescheduling proposal if the proposal offers the party at least as much in discounted present value as it can hope to obtain by waiting, given the strategies of both the banks and the country. In equilibrium, the following conditions will have to hold $\forall s \geq t, \quad s-t$ even: $:^{15}$

$$
\begin{gathered}
(1-q(t, s))=\max \left[\left(1-q^{\prime}(t, s+1)\right) \frac{(1-\gamma h)}{(1+\delta h)}, 1 / P,(1-\beta)\right], \\
q^{\prime}(t, s+1)=q(t, s+2) \frac{(1-\gamma h)}{(1+r h)} .
\end{gathered}
$$

Equation (6) states that for the bank's offer in period $s$ to be acceptable to the country, it must give the country as much (in discounted utility terms) as the maximum of what the country could get if it (a) turned down the offer and made a minimum acceptable counteroffer in the next period; (b) simply consumed the output domestically; or (c) shipped the goods without a rescheduling agreement and suffered the attendant losses through seizure. Equation (7) states that if the country makes an offer in period $s+1$, it must offer the bank as much (in present value) as the bank would get if it turned down the country's offer and made a minimum acceptable counteroffer in the next period.

The logic underlying equations (6) and (7) is that if it is either party's turn to make an offer, it will offer the minimum acceptable to the other party. The other party will accept any offer that makes it better off than in the subgame where it refuses that offer; thus the minimum acceptable offer is the one that gives the other party exactly as much utility as it would get in the subgame where it rejected the offer. Clearly, the offerer will do better

15 By writing each side's offer only as a function of time, we have implicitly ruled out history-dependent strategies. Rubinstein (1982) has shown that in this two-player bargaining framework, history-dependent strategies cannot be equilibrium and indeed, there is a unique perfect equilibrium. For a very simple proof of Rubinstein's results, see Shaked and Sutton (1984). Their proof can be applied directly to the present problem. 
by offering this minimum rather than having an offer rejected. For then the other party will end up getting the same utility, and since the gains from trade will be realized a period later, the offerer will be worse off. Of course, there is no point in making more than the minimum acceptable offer.

The unique equilibrium rescheduling agreement is given by the stationary equilibrium of the system of difference equations governed by (6) and (7) [It is a simple matter to show that any path which obeys (6) and (7), and does not initiate at the unique stationary equilibrium, will violate the boundary condition that neither side's share can exceed one.]:

$$
q=\min \left(\frac{h(\gamma+\delta)(1+h r)}{h\left[2 \gamma+\delta+r+h\left(\delta r-\gamma^{2}\right)\right]}, \frac{P-1}{P}, \beta\right)
$$

Note that the parties always reach an agreement without delay. The bargaining always produces an efficient outcome. In the limit as $h \rightarrow 0+$ (continuous bargaining), (8) becomes

$$
q=\min \left(\frac{\gamma+\delta}{2 \gamma+\delta+r}, \frac{P-1}{P}, \beta\right) \text {. }
$$

Equation (9) indicates that the equilibrium rescheduling agreement will fall into one of three regions, depending on which of the three right-hand side terms in (9) is the minimum. We call these the bargaining region, the autarky-constrained region, and the punishmentconstrained region respectively. Note that the three RHS terms in (9) each depend on entirely different parameters, and are monotonic in all their arguments. Therefore, varying any one parameter of the model will only affect the value of one term and will not affect the relative ranking of the other two regions.

In the bargaining region, the bank gets $P \bar{y}(\gamma+\delta) /(2 \gamma+\delta+r)$, and the country gets $P \bar{y}(\gamma+r) /(2 \gamma+\delta+r)$. A crucial feature here is that the banks' receipts are linear in the world market value of the country's production of tradeables, not just the gains from trade $(P-1) \bar{y}$. The reason that the bank can effectively bargain over the gross value of tradeables and not just the country's gains from trade, is that the country's threat to either consume the goods or ship them without a rescheduling agreement is not perfect, and therefore irrelevant. That is, for example, the country cannot present the bank with a rescheduling offer and tell the banks that if this offer is not accepted, the country will consume the goods. The reason is that if the banks refuse the offer, the country will not make good on its threat since it will be better off if it continues to bargain. Thus, the fact 
that these goods have some value to the country in domestic consumption does not affect the equilibrium.

The relative shares of the two parties in the bargaining region are in inverse proportion to their rate of impatience in reaching a settlement, $\gamma+\delta$ for the country and $\gamma+r$ for the banks. Note that the rate of impatience for each side is determined not just by their respective rates of time preference, but also by the rate at which the good deteriorates in storage, $\gamma$. If $\gamma$ is large, as with nondurable exports, then the shares in the bargaining region are roughly equal. Note that the assumption of storeability does not prevent us from applying our paradigm to a country which exports bananas. Think of the country as holding the bananas in port, awaiting a rescheduling agreement. As long as a series of counteroffers can be exchanged in the time it takes for the bananas to rot, the banks cannot simply make take it or leave it offers.

The higher the world interest rate, $r$, the less a country (which owes an infinite amount) will have to pay. When world interest rates rise, the banks become more impatient to get their money out of the country, and into high-yielding investments elsewhere. The country can exploit this impatience to its advantage. ${ }^{16}$ This logic underlies our result in section IV that an unanticipated rise in world interest rates can actually favor the debtor country. In the non-stochastic model of this section, however, higher world interest rates will always make the country worse off because they are perfectly anticipated. We shall expand on this point shortly and then again in section IV.

When the gains from trade are small $[P<(2 \gamma+\delta+r) /(\gamma+r)]$ and the potential costs of seizure are relatively high $(1 / P>1-\beta)$, then the country's threat to consume in the absence of a bargaining agreement becomes credible. In this autarky region, the payments to the banks prescribed in the bargaining region exceed the total gains from trade. However, an agreement is always reached because the banks will find it in their interest to make an offer allowing the country to trade for a payment just infinitesimally smaller than the total gains from trade. Within the autarky region, the level of repayments is extremely sensitive to the world market price of the country's output, $P$. While in the other regions, a fall in $P$ affects the banks and the country proportionately, in the autarky-constrained region any

16 Given that $\delta>r$ if the spread between the two is a constant, a rise in both rates still hurts the banks' bargaining position. 
drop in the relative price of exports causes a loss borne solely by the banks.

If $\beta$ is the minimum argument on the right-hand side of (9), the country's threat to trade without an agreement is credible. The punishment-constrained region is the relevant one whenever the banks have very little ability to impose damage on the country's trade. Interestingly, in the punishment-constrained region, the bargaining equilibrium is the same as the equilibrium when banks can make take-it-or-leave-it offers. ${ }^{17}$ The model thus provides a rationalization for the equilibrium discussed in Eaton and Gersovitz (1981), Sachs (1984), Folkerts-Landau (1985), and others. In the punishment-constrained region, the bank gets $\beta P \bar{y}$ and the country does not have any way to negotiate a lower payment. It cannot credibly commit to refusing an offer which gives it infinitesimally more than $(1-\beta) P \bar{y}$, the amount it would get from shipping without a rescheduling agreement. The reason is that such an offer is already as good as the country can hope to get through continued bargaining. The key to this result is that bargaining enables the bank to negotiate over the country's entire production of tradeables, and not just the amount of damage the banks could impose on the country, $\beta \bar{y}$.

While the banks' ability to inflict damage on the country through seizure sets a limit on its repayments, the ability to increase seizures does nothing for the banks outside of the punishment-constrained region. An increase in $\beta$ has no effect on debt payments in the bargaining region. It also would not help the banks to be able to reduce the deadweight loss involved in the seizure technology. So long as the banks get any positive net revenues from seizure, i.e. $\alpha>0$, it is completely credible for the banks to threaten maximal seizure activities if the country tries to ship without a rescheduling agreement. On the other hand, if the equilibrium is in the bargaining region, it does not matter if $\alpha P \bar{y} \geq P \bar{y}(\gamma+\delta) /(2 \gamma+\delta+r)$, in which case banks obtain less through bargaining than they would if the country traded without a rescheduling agreement. The banks' difficulty is that they cannot initiate seizures until the country initiates trade; this is why the size of $\alpha$ does not matter. ${ }^{18}$

The maximum amount the country can borrow is calculated by taking the present value

17 Obviously, this is also the case in the autarky region.

18 If $\alpha<0$, then the banks' threat to seize shipments is not credible and they won't be paid a peso in a perfect equilibrium. In this case, one would need to appeal to a reputational supergame argument to rationalize any equilibrium in which repayments (and also loans) are made. It seems quite plausible to assume $\alpha>0$ at some level of seizure activity whenever the country trades at the efficient level $(T=\bar{y})$. 
of the maximum repayments it would make if it had a (nominally) infinite liability. Such a loan would give the banks annual payments equal to what is prescribed by (8) or (when $h$ is small) by (9), discounted by the interest rate $r$. Thus, the maximum loan when $h$ is small approaches: ${ }^{19}$

$$
\Re=\left(\frac{P \bar{y}}{r}\right) \min \left(\frac{\gamma+\delta}{2 \gamma+\delta+r}, \frac{P-1}{P}, \beta\right) .
$$

Note that a higher value of $r$ can reduce the maximum loan in two ways. First, a higher discount rate makes the present value of any given stream of repayments less valuable to the bank. Second, if equilibrium is in the bargaining region, an increase in the discount rate of the banks makes them worse bargainers and thus decreases the level of payments in every period. Since we have assumed that banks are competitive and earn zero profits on their initial loans, both factors will necessarily imply a loss of utility to the country's leaders. ${ }^{20}$ Of course, we have been assuming that the country's output is not growing. If its output grows at rate $g$, then the term $P \bar{y} / r$ in $(10)$ becomes $P \bar{y} /(r-g) \cdot{ }^{21}$ If the country's growth rate exceeds the relevant interest rate, the country can borrow as much as it wants. The growth rate statistics in the Appendix suggest that there is a significant chance that $g$ will be less than $r$ (on average) into the forseeable future for many major debtors.

\section{Stochastic Output and Interest Rates}

In the absence of uncertainty, rational banks will never lend the country more than it can be bargained into repaying. ${ }^{22}$ This is not necessarily the case once we allow for uncertainty in the country's output, the terms of trade, or world interest rates. With uncertainty, 19 In (10) and in the remaining formulas in the paper, we have taken the limiting expres-
sion as $t^{*} \rightarrow \infty$.

20 After a consortium makes an initial loan to the country of size $\Re$, no other lender will ever enter. Our assumptions concerning legal rights insure that the initial lenders will get at least as high a rate of return as any future lenders. Once the country has borrowed to the hilt, any new loans will not increase total repayments. Hence, additional lending would make lenders as a class, and new lenders in particular, losers.

21 One possible extension of the model would be to introduce investment along the lines of Cohen and Sachs (1986), and Sachs (1984). If the country can precommit to invest some part of its share of the gains from trade, creditor banks will accept lower current repayments. When the country invests, its future path of output rises, and the banks know they will be
able to collect more later on.

22 Anticipated defaults can occur in the model of section V, in which the U.S. is coerced into making a fraction of the country's payments. 
the maximum amount the country will pay each period fluctuates. ${ }^{23}$ Most of this section will be devoted to determining what the implicit contract between the country and the banks must be. Although payments fluctuate, there is never any need to formally recontract, so long as the explicit legal contract is fully state contingent and corresponds exactly to the implicit contract which can be supported as a bargaining equilibrium. Towards the end of this section, we discuss reasons why reschedulings may sometimes be needed.

The maximum amount the country can borrow, $\Re$, obviously depends on the probability distribution of the maximum payments the country will pay. The simplest case is when output is stochastic, since repayments are linear in output, and since the level of output has no effect on the banks' share. If output is distributed with probability density $f(y)$ along the interval $\left[y^{\min }, y^{\max }\right]$, then the country's collateral is given by:

$$
\Re=q P \int_{0}^{\infty} e^{-r s} \int_{y^{\min }}^{y^{\max }} y f_{s}(y) d y d s,
$$

or equivalently

$$
\Re=q P \int_{0}^{\infty} e^{-r s} E\left(y_{s}\right) d s
$$

where $E\left(y_{s}\right)$ is the expected value of period $s$ output, conditional on time zero information. Because $\delta>r$, the country will clearly borrow $\Re$ immediately in return for incurring obligations that will lead to the same stream of repayments as infinite debt.

Stochastic interest rates present slightly more technical problems, since our analysis of bargaining imposed constant interest rates. Whereas it is feasible to extend our bargaining model to allow for fairly general stochastic processes for interest rates, we shall only analyze a special simple case, one which nevertheless allows us to bring out some important points.

We shall assume that there will be a one-time permanent change in the world interest rate, occuring at some random time $t$ with the density function $\lambda e^{-\lambda t}$ for $0 \leq \lambda \leq \infty$. When the shock occurs, the post-shock interest rate will be $\tilde{r}$, where $\tilde{r}$ is distributed with probability density $g(\tilde{r})$ along the positive interval $\left[r^{\min }, r^{\max }\right], r^{\max }<\delta$. In this case, the collateral the country has to offer can be thought of as the sum of two claims, one of which pays $\tilde{q} P \bar{y}$ in all periods after the shock (where the banks' share $\tilde{q}$ is a function of

23 Risk sharing is not an issue here, since both the country and the banks are risk neutral. It is the fact that $\delta>r$ which creates a role for international lending. 
the realization of $\tilde{r}$ ) and one of which pays a fixed amount $q^{\Phi} P \bar{y}$ in all periods prior to the shock.

The value of the claim which only requires payments in the post-shock period is:

$$
\Re=P \bar{y} \int_{0}^{\infty} \lambda e^{-(\lambda+r) t} E(\tilde{q} / \tilde{r}) d t=P \bar{y} \lambda E(\tilde{q} / \tilde{r}) /(r+\lambda) .
$$

That is, after the shock the banks get a perpetuity with payments at rate $\tilde{q} P \bar{y}$, discounted forever at rate $\tilde{r}$. The likelihood that the perpetuity will begin in year $t$ is $\lambda e^{-\lambda t}$, and the present discounted value of a dollar in year $t$ is $e^{-r t}$. Similarly, the value of the loan on which payments are received only before the shock is

$$
P \bar{y} \int_{0}^{\infty} e^{-(\lambda+r) t} q^{\Phi} d t=P \bar{y} q^{\Phi} /(r+\lambda)
$$

The maximum amount the country can borrow, $\Re$, is found by adding (13) and (14). ${ }^{24}$

An increased probability of high interest rates unambiguously lowers the amount the country can borrow. Suppose one distribution of post-shock interest rates, $A$, is created from another distribution, $B$, by shifting probability mass from the low tail of $B$ to the high tail. Then the country can borrow more if interest rates are governed by distribution $B$. A higher distribution of interest rates implies that future payments are discounted more heavily. Also, a higher post-shock interest rate never raises the country's payments $\tilde{q} P \bar{y}$, and will lower them if equilibrium is in the bargaining region. The result here that an increased probability of high interest rates is bad for the country is the stochastic analogue of our result in section III concerning a fully anticipated increase in world interest rates. However, although anticipated interest rate increases are bad for the country, it may benefit by an unanticipated interest rate increase. It is a simple matter to show that this is the case once the country is "loaned up"; that is, when it has already committed to a stream of repayments greater than it can be forced to repay. An unanticipated interest rate increase will then either reduce or leave unchanged the payments the country will have to make. This result holds even if the interest rate the country is supposed to pay is nominally "indexed"

${ }^{24}$ In general $q^{\Phi}$ does not equal $\bar{q}$, the level of payments the country could be forced to make if no shock were ever anticipated. That is because the bargaining over each unit is affected by the possibility that the banks' opportunity cost of waiting may change at some point. However, our bargaining model can still be solved when uncertainty about interest rates follows a Poisson process, and it is a simple matter to derive $q^{\Phi}=(\delta+2 \lambda E(\tilde{q})) /(\delta+$ $2 \lambda+r)$, (as $h \rightarrow 0+$ ). Hence if $E(\tilde{q}=\bar{q})$, then payments in the preshock period will be $\bar{q}$. 
to the world interest rate. Thus the fact that there are more defaults when interest rates rise may not simply be a result of debtor countries' inability to handle the excess debt burden. It can also be due to the way in which high world interest rates improve a debtor's bargaining position. Payments can actually go down.

To be concrete, suppose that country $M$ initially has debts with a face value of 100 billion dollars. Assume that inflation is two percent, that interest rates are seven percent, and that the country is making payments of five billion dollars per year. Hence the nominal value of its debt is rising by two percent per year, and the real value is constant. Our model suggests the possibility that when interest rates rise to ten percent (with inflation remaining at two percent), $M$ 's payments might actually fall to four billion dollars (perhaps with the face value of this loaned-up country's debt being increased nominally and meaninglessly by six billion dollars.) Obviously, there are many qualifications to the above result. An unanticipated interest rate increase is not necessarily good for the country before it is "loaned up".

Finally, we come to the question of how optimal sovereign lending contracts should be written. The issue is how to make best use of the country's only vehicle for legal precommitment, the U.S. courts. We will assume that the country's discount rate is higher than the world interest rate in all states, so that the country would like to borrow the maximum possible amount. The optimal legal contract is one which gives the banks enough bargaining power to assure ex ante that they will be able to collect the maximum possible amount in all states of nature. Whereas such a contract implicitly gives the banks a contingent claim on the country's production, there are at least two (closely related) reasons (within the scope of the model), why it will be in the interests of the parties to formally label the country's obligations "debt". First, suppose instead that the banks are given equity in the country's export industries. Then if the country later adopts a policy interfering with repatriation of dividends, or if it taxes exports, the banks' share is reduced and they do not have the same legal recourse given to them by a loan default. Second, and perhaps more relevant to the case of productivity uncertainty, the variables which determine repayments may be observable, but not verifiable. That is, although both parties may have equal knowledge about developments in the country's productive capacity, it may be difficult to develop evidence which will stand up in U.S. courts. Most debtor countries do not publish national 
GNP accounts and, even if they did, these could be distorted in a way which be difficult to document. Therefore, it may be impossible to write enforceable contracts which are explicitly contingent on the key repayment variables. Hence, there may sometimes be a need to write rescheduling agreements.

From the above discussion, we can see why the optimal legal contract might involve having the face value of the debt will be set so high that the country will partially default in all but the most favorable states of nature (unless, of course, shocks are verifiable). As a detail, we might mention that it is irrelevant how the discrepancy between the market value and the face value of the original loan is created. Debt can be sold at an original issue discount, or the banks can impose large service fees on the country, so that the amount of money given the country is less than the face amount of the loan.

One further reason why the explicit contract between the banks and the country may deviate from the implicit contract has to do with sidepayments from the U.S., an issue we'll consider next. Since it's not possible to write these sidepayments into the contract, it may be necessary to have actual rescheduling negotiations in order to get the U.S. to kick in its share.

\section{U.S. Government Intervention}

Until now, our model has not allowed for any possible U.S. government (U.S.) involvement in the rescheduling process. ${ }^{25}$ In this section, we consider what role the U.S. might be willing (or forced) to play if it is concerned about maintaining its gains from trade. Whenever a country repudiates its $d e b t$ and the banks begin seizure activities, then the consequent reduction in trade adversely affects U.S. consumers and producers.

One can certainly think of other reasons why the U.S. might be drawn into the negotiations. The most often cited reasons are fear of a banking crisis and Federal deposit insurance. It should be possible to extend the model developed below to incorporate these factors, but it is not certain how important they are either from a normative or a positive

${ }^{25}$ Except, of course, that the U.S. legal system plays a crucial role in the analysis of sections III and IV. In this section, we treat the U.S. legal system as constitutionally immutable, and therefore not subject to manipulation by the congressional or executive branch which we refer to as the U.S. government. The executive branch may have some control over intensity of enforcement; here it will always choose the minimum possible level. We intend to examine this issue in more detail in future research. 
point of view. Whereas the equity of U.S. banks may not be sufficient to absorb a total repudiation of all their holdings of LDC debt, the banks have built up their capital in recent years $^{26}$, and can now absorb a large writedown on LDC debt. (The secondary market transactions cited in footnote 2 provide only a partial guide for determining the true value of the loans. The problem is that these prices may already reflect anticipated U.S. government assistance.) And even if some bankrupt banks do have to be reorganized, these can probably be absorbed into the banking system without any great loss of financial intermediation services. A significant advantage to the gains from trade rationale over the FDIC/banking crisis rationale, is that the former simultaneously explains banks' bargaining power. The desire to preserve gains from trade explains why the U.S. can't force bank stockholders to absorb most or all the losses. It also explains why banks from other Western countries also have some leverage with the U.S.. Banks have bargaining power because of their legal rights to interfere with trade if the country defaults on its debt.

A central conclusion of our analysis is that even if the gains from trade are important to the U.S., the U.S. will generally be better off it it can precommit to stay out of the rescheduling process. And although it would be better to make this precommitment before the loans are made, it is still the best policy even in the event of a default crisis. The point is that the banks and the country will always arrive at an efficient bargain, and this means there will be no interruption of trade. It is not necessary for the U.S. to kick in sidepayments to ensure an outcome which is already in the banks' and the country's best interests. Unfortunately for the U.S. - and this is the other main point of the section it may have no way to credibly commit not to bargain. The banks and the country can exploit the U.S.'s desire to enjoy its gains from trade sooner rather than later. In a perfect equilibrium, the U.S. can be bargained into making sidepayments.

At this point, we are forced to make a slight digression to derive the U.S.'s objective function. Obviously, it is possible to motivate the U.S.'s gains from trade by positing that the country is the sole supplier of a strategic resource, or that it is a large trading partner. But in the interests of maintaining internal consistency with the model of sections II-IV,

26 In June 1982, the ratio of U.S. bank capital to developing countries loans was 50 percent. By June 1985, this ratio had risen to 71 percent. For the largest nine banks, the ratios are lower but the trend is the same. Their capital/developing country loan ratio was forty percent at the end of 1984. See Watson et al (1986), Table 34 and chart 10. 
we seek a rationale consistent with the country being small and a price-taker in world markets. How is it possible that a small price-taking country can have bargaining power? ${ }^{27}$ One answer is as follows: Suppose that the U.S. and the country are the world's only potential consumers of good $D$, the good produced and exported by the country. The U.S. imports good $D$ from a large number of competitive suppliers abroad, but there are no U.S. producers. All the foreign producers, except the country, have inelastic supply curves; their total supply is $\bar{Q}-\bar{y}$. Moreover, there are no storeage facilities in the U.S. so that once good $D$ is shipped to the U.S., it must be consumed immediately (once picked, the produce ripens quickly).

Let $V(Q)$ denote total U.S. consumer surplus, and let $U(Q)$ denote the utility of the marginal U.S. consumer when total consumption is $Q$. Then if the total supply to the U.S. is $\bar{Q}$, consumer surplus is given by

$$
V(\bar{Q})=\int_{0}^{\bar{Q}} U(Q) d Q-\bar{Q} U(\bar{Q}),
$$

where we have made use of the market equilibrium condition $P=U(\bar{Q})$. A small reduction in the amount of good $D$ shipped to the U.S. leads to a loss of consumer surplus given by

$$
\frac{d V}{d Q}=-Q \frac{\partial U}{\partial Q}=z U(Q)
$$

where $z=-(\partial U / \partial Q)(Q / U)$ is the inverse of the elasticity of demand for good $D$. Hence if the country is small, the U.S. will lose $z P \bar{y}$ in current consumer surplus per period if the country's goods are permanently withheld from the U.S. market. ${ }^{28}$ We have assumed that the supply functions of the other foreign producers are inelastic. If they are elastic, then the U.S. would get less consumer surplus from trading with the country; if perfectly elastic, then the U.S. gets no benefit.

Note that the country would have no way to exploit its bargaining power were it not for the existence of the U.S. government. It is only through the government that the country

27 Dixit (1986) discusses a number of reasons why smallness may not be a handicap in strategic trade negotiations. To our knowledge, however, the approach adopted here is novel.

28 We shall assume that the maximum amount of good $D$ the country can put on the U.S. market (from production and out of storage) is sufficiently small so that the marginal gains from trade for the U.S. are approximately constant. (Sufficient conditions include a high depreciation rate, $\gamma$, or a short time horizon, $t^{*}$.) 
can bargain with U.S. consumers. A second essential factor is the assumption that good $D$ is not produced in the U.S.. Consider the other extreme where all production (except the country's) is based in the U.S.. Then, although a suspension of trade with the country still implies a loss of surplus for U.S. consumers, this loss is (approximately) cancelled out by a gain in producers' surplus.

From (16), it is apparent that the country's bargaining power is only of the same order of magnitude as its output and debt repayments. Hence if the country produces two dollars of output (per period), its bargaining power will be on the order of one dollar, and not one hundred million dollars. Note that the country's debt repayments will also be of the same order of magnitude as its output.

We will assume that the U.S. government seeks to maximize the presented discounted value of current and future expected consumer surplus: ${ }^{29}$

$$
\Psi_{t}=\sum_{i=0}^{\infty}\left[h z P\left(1-\beta X_{t+h i}\right) T_{t+h i}-B_{t+h i}\right] /(1+r h)^{i},
$$

where $B$ represent sidepayments by the U.S. to the banks and/or country. In (17), we have assumed that the U.S. government discounts future costs and benefits at the world interest $r$; this assumption seems natural but does not qualitatively affect our results.

Having discussed the U.S.'s interest in the negotiations between the country and the banks, we are now ready to be more specific about the three-way bargaining process. Any resched uling contract must be signed by both the banks and the country. The U.S.'s consent is not required unless the agreement calls for the U.S. to make positive sidepayments. If the banks and/or the country choose to bring the U.S. into the bargaining, each of the three parties will take turns making offers. It will be convenient to restrict our attention to the case where $1 / P>1-\beta$, so that the relevant threatpoint for the country is autarky. (We shall also assume that $\beta>(\gamma+\delta) /(3 \gamma+2 \delta+r)$; this assumption will turn out to preclude any threat by the U.S and the country to deal out the banks.) Then the total surplus to

${ }^{29}$ If bank profits are taxed, the U.S. government also benefits from any payments the country makes to the banks. It is straightforward to show that the qualitative effect of introducing this consideration is to raise the sidepayments the U.S. can be bargained into making. It is perhaps simplest for purposes of this section to assume that the country's creditor banks are located in other Western countries, ones which do not produce or consume good $D$. This also helps justify the simplifying assumption that the banks' stockholders do not enter into the U.S.'s utility function. 
be divided up among the three parties is the sum of the U.S.'s gains from trade, $z P \bar{y}$, and the country's gains from trade, $(P-1) \bar{y}$; if an agreement is not reached immediately, then of course these amounts decline at rate $(1-\gamma h)$ as the good depreciates. For notational purposes, it will be convenient to specify each party's offer in terms of shares of $(1+z) P \bar{y}$. Thus when it is the banks' turn to make an offer, it offers the country $100(1-q-w)$ percent of remaining $(1+z) P \bar{y}$, and the U.S. $100 w$ percent. The country's offer to the banks is $q^{\prime}$, and to the U.S., $w^{\prime}$. The U.S.'s offers are $q^{\prime \prime}$ to the banks and $1-q^{\prime \prime}-w^{\prime \prime}$ to the country. Following the same steps as in Section III, one can show that in any perfect equilibrium with history-independent strategies, the following conditions must hold $\forall s \geq t$, where $s-t$ is a multiple of three: ${ }^{30}$

$$
[1-q(t, s)-w(t, s)]=\max \left\{\left[1-q^{\prime}(t, s+1)-w^{\prime}(t, s+1)\right]\left(\frac{1-\gamma h}{1+\delta h}\right), \frac{1}{(1+z) P}\right\}
$$

$$
w(t, s)=\min \left[w^{\prime}(t, s+1)\left(\frac{1-\gamma h}{1+r h}\right), \frac{z}{1+z}\right]
$$

$$
w^{\prime}(t, s+1)=\min \left[w^{\prime \prime}(t, s+2)\left(\frac{1-\gamma h}{1+r h}\right), \frac{z}{1+z}\right]
$$

$$
\begin{aligned}
& 1-q^{\prime \prime}(t, s+2)-w^{\prime \prime}(t, s+2)=\max \left\{[1-q(t, s+3)-w(t, s+3)]\left(\frac{1-\gamma h}{1+\delta h}\right), \frac{1}{(1+z) P}\right\} \\
& (18 f) \quad q^{\prime \prime}(t, s+2)=q(t, s+3)\left(\frac{1-\gamma h}{1+\tau h}\right) .
\end{aligned}
$$

${ }^{30}$ As in Section III, there is only one solution to the system of difference equations governed by equations (18) which does not violate the boundary condition that no party's share can exceed one. However, unlike in the two-player game, in the three-player game one must make stronger assumptions to rule out history-dependent strategies. As Sutton (1986) discusses, any number of reasonable assumptions will rule out those "perverse" equilibria. For example, the equilibrium of the finite horizon bargaining game is unique, and approaches (19) as the horizon becomes very large. Also, (19) is the unique "strong" equilibrium, and the unique equilibrium when strategies are continuous in the history of the game. 
Equation (18b) embodies the constraint that the U.S. will only be allowed to bargain if it makes positive sidepayments. Equation (18a) embodies the constraint that the country must do at least as well by rescheduling as it would by going into autarky. When neither constraint is binding, the equilibrium shares with continuous bargaining $(h \rightarrow 0+)$ are

$$
q=w=\frac{\gamma+\delta}{3 \gamma+2 \delta+r}
$$

$$
1-q-w=\frac{\gamma+r}{3 \gamma+2 \delta+r}
$$

As in Section III, an agreement is reached immediately. If the U.S.'s share in (19a) exceeds its gains from trade, then the U.S. is kept out and the shares are as in Section III. If the U.S. is in, but the autarky constraint is binding, then the U.S. and the banks split the total gains from trade evenly. Each gets $[(1+z) P-1] \bar{y} / 2$. In all cases, the U.S.'s actual payment to the country and the banks is $P \bar{y}[z-w(1+z)]$. Note that if

$$
z P \bar{y}-\frac{(1+z) P \bar{y}(\delta+\gamma)}{3 \gamma+2 \delta+r}>0
$$

so that the U.S. is making positive sidepayments in a three-way bargaining-region equilibrium, then by equations (9) and (19) it must also be true that

$$
\begin{aligned}
& \frac{(1+z) P \bar{y}(\delta+\gamma)}{3 \gamma+2 \delta+r}-\frac{P \bar{y}(\delta+\gamma)}{2 \gamma+\delta+r}>0, \\
& \frac{(1+z) P \bar{y}(r+\gamma)}{3 \gamma+2 \delta+r}-\frac{P \bar{y}(r+\gamma)}{2 \gamma+\delta+r}>0,
\end{aligned}
$$

so that both the banks and the country get a larger payoff with the U.S. involved. Thus there is no conflict in deciding whether or not to bring in the U.S..

If the U.S.'s eventual involvement in the bargaining process is fully anticipated, then the country will be able to get a larger loan. As in section III, the maximum loan the country can get depends on the present discounted value of the banks' share in any rescheduling agreement, or

$$
\Re=q(1+z) P \bar{y} / r \text {. }
$$


If condition (20) holds, then the amount given by (23) and (19a) is strictly larger than the amount dictated by equations (9) and (10).

There is a very important distinction between anticipated U.S. sidepayments, and unanticipated sidepayments. Unanticipated U.S. sidepayments benefit both the banks and the country. But the benefits of fully anticipated sidepayments accrue entirely to the country. Banks are competitive and earn zero profits on the loan (if there are no surprises). Therefore, the anticipation of U.S. sidepayments just means that the country can take out a larger loan, with the U.S. meeting the additional payments. As a detail, we should observe that the amount given by (23) and (19a) does not exceed the amount given by (10) and (9) by the full present discounted value of the U.S.'s sidepayments. That is because banks anticipate that with the U.S. involved, the country will achieve a better bargain for itself each period. Hence, the country is not able to increase its borrowing by the full capitalized value of the U.S.'s sidepayments, even though with $\delta>r$, it would like to.

How can sidepayments can be squeezed out of the U.S., even when it knows that the banks and the country will arrive at a rescheduling agreement without its help, and that this agreement will fully protect the U.S.'s gains from trade? The U.S.'s problem is that when its gains from trade are of the same order of magnitude as the country's, the banks and the country can exploit the U.S.'s impatience for them to reach an agreement. If the U.S.'s stakes are large enough, it cannot credibly refuse to bargain. If the U.S. wishes to avoid making undesired sidepayments, it could tamper with its legal system, but this presumably would have large negative side effects. If the U.S. desires to give foreign aid to the country, in excess of the sidepayments it would have to make in any rescheduling negotiations, then the advent of debt merely converts a voluntary gift into a coerced contribution.

Another question which needs to be addressed is why the country needs to use the banks to exploit its bargaining power in trade vis-a-vis the U.S.. One answer to this is that U.S. would be unwilling to make a lump-sum transfer unless the country can precommit not to borrow from the banks. But a deeper answer is that the country can actually use the banks to its advantage in bargaining with U.S.. To isolate this point, let us temporarily assume that the country has the same discount rate as the U.S. and the banks; hence lumpsum loans are not necessary for efficiency. Suppose further that bank loans to the country are impossible, because U.S. courts will not enforce the contracts. The country may still be 
able to extract a flow of sidepayments from the U.S., by holding up exports at its border. The country simply refuses to export in any given period until it simultaneously receives a sidepayment from the U.S.. By bargaining directly with the U.S., the country is able to get an even split of the total surplus of $\bar{y}(1+z) P / 2$ (since we have now specified that the country and the U.S. have equal discount rates). This share is larger than the country gets under (19b), with banks in the bargaining, and if $z>1$, exceeds the country's share under free trade. But this does not imply that the country would be better off foregoing bank loans, since any share going to the banks is only a repayment of funds which were previously loaned to the country. With bank loans, the country gets roughly two-thirds the surplus instead of one half. The country can more effectively exploit its bargaining power with the U.S. by bringing in the banks! This perspective is in sharp contrast to the popular image of the U.S. and the banks teaming up against the country.

In concluding this section, we remark that the U.S.'s sidepayments can take many forms other than cash payments: military assistance, changes in U.S. immigration and drug laws, a lowering of tariffs, and so on.

\section{Non-Cooperative Banking Consortiums and Pluralistic Political Parties}

Throughout, we have assumed that the banks which make up the banking consortium act as one monolithic agent, and that the diverse interests which make up the country's leadership act as another. Clearly these assumptions are not entirely realistic. The point of this section is to show that the key assumption underlying our earlier analysis concerns the relative bargaining power of the banks as a whole versus the country's leadership as a whole. Even though the model does not indicate how payments are split up among the banks, it can still indicate the determinants of the split between the banks and the country.

To illustrate this point, let us return to the model of section III (no uncertainty and no U.S.). Now suppose that the country has less bargaining power in that it is only able to make one third of the total offers, instead of half. In other words, the country makes an offer every third period, and the banks make offers in the other two periods. Following the same steps as in section III, it is straightforward to show that in a perfect equilibrium (and as the time period becomes small)

$$
q=\min \left(\frac{2(\gamma+\delta)}{3 \gamma+2 \delta+r}, \frac{P-1}{P}, \beta\right) .
$$


A comparison of (9) and (24) indicates that if equilibrium falls in the bargaining region, banks receive a higher payment (roughly $2 / 3$ instead of $1 / 2$ of GNP) when they can make two thirds the offers instead of one half the offers.

Let us now assume that instead of there being single banking consortium, there are two bank creditors, $A$ and $B$. Each holds half the country's debt, and each can unilaterally conduct seizure operations if the country tries to trade without a rescheduling agreement. If the bargaining process is such that the country and banks take equal turns making offers (first bank $A$, then bank $B$, then the country), then it is straightforward to show that the country pays each bank $q / 2$, where $q$ is given by equation (24). Suppose instead that the country bargains evenly against the two banks (first bank $A$ makes an offer, then the country, then bank $B$, then the country). Then it is easy to show that the country only makes total payments as given by (9). Obviously, both sides have an incentive to take steps to increase their bargaining power. (In this vein, it seems important to recognize that debtor countries may be able to implicitly coordinate their behavior.)

The real point is that our model, which is based on Rubinstein's work, does not endogenize every conceivable element of the bargaining process. The exogenous elements are summarized in the percentage of offers each side is allowed to make. Our Rubinstein-type model does successfully endogenize some aspects of bargaining, such as the effect of relative discount rates, and of threat points. This would seem to be an advance over "take it or leave it" models of bargaining, but clearly it would be useful to incorporate richer models of bargaining into future research on rescheduling agreements.

\section{Conclusions}

An implicit assumption in many earlier models of sovereign lending is that banks can restrict a debtor country's options to two choices: default and full repayment. In this paper, we recognize that debtors realistically have a third option, which is to bargain over repayments. Bargaining may be a viable option even in situations where banks have considerable means to reduce the country's current and future gains from trade. A debtor can bargain because banks will receive nothing unless the country is allowed to export its goods, and because while negotiations are proceeding, the goods are depreciating and the banks are foregoing in terest. The level of loans a country can commit to repay thus may be even lower 
than has been previously recognized.

In our model, the only "collateral" a country has to offer is a percentage of its gains from trade. Banks can inflict this cost on the country because any sovereign borrower will (in equilibrium) sign contracts maximizing its creditors' legal rights. Exactly how extensive these rights may be is uncertain ${ }^{31}$; there is limited legal precedent. There is little precedent because sovereign repudiations almost never occur; debtors and creditors find it more efficient to reschedule. In their seminal paper, Eaton and Gersovitz (1981) consider the possibility of direct penalties but choose to stress primarily a second incentive for countries to repay: the threat of financial autarky. Eaton and Gersovitz argue that the main reason for sovereign borrowing is likely to be short-term consumption smoothing. Countries lend when their income is high and borrow when it is low. Hence, according to Eaton and Gersovitz, bank loans to sovereign debtors will typically be repaid quickly. Countries will try to avoid defaulting because otherwise they will face prolonged financial autarky; this can be an equilibrium outcome in an infinite-horizon reputational model. The threat of financial autarky may be important in some instances and it should be possible to extend our bargaining framework to incorporate such cases. However, the debt/GNP ratios listed in the Appendix lead one to be skeptical of whether financial autarky is a significant consideration for today's major problem creditors. The ratio of debt to GNP for these major debtors is in most cases greater than fifty percent, and in some cases over one hundred percent. The loans are patently not short term. It seems totally implausible that the rulers of these countries have discount rates so low that they will repay these debts over the next twenty or thirty years, primarily in order to be eligible to borrow (or lend) again sometime well into the next decade. The supergame short-term consumption smoothing argument also seems at odds with other aspects of the data. Non-oil developing countries experienced severe adverse transitory terms of trade shocks at the beginning of the 1980 's. ${ }^{32}$ It is precisely when their income dropped that they stopped being able to borrow. The same is the case for Mexico, whose ability to borrow fell with falling world oil prices. (Note: If the country's policymakers are risk-averse, consumption smoothing can occur in a model

\footnotetext{
31 Kaletsky (1985) conjectures that creditor's legal redress over sovereign default is quite limited, but recognizes the paucity of legal precedent.

32 At the end of 1985, the World Bank's non-oil commodity price index was down 26 percent from its end of 1980 value. (See World Bank Debt Tables, p. xv.)
} 
such as ours. However, outside an infinite horizon supergame struture, the desire to smooth consumption alone will not induce repayments. Legal sanctions are necessary.)

Clearly there does exist some mechanism to induce repayment; otherwise there would never be periods where banks receive net payments (that is, where a problem debtor's external liabilities grow at less than the rate of interest). As the Appendix documents, most of the major problem debtors actually ran trade balance surpluses in 1984. And in the twelve months ending in June 1985, U.S. bank loans to Argentina grew at $-3.2 \%$, to Brazil at 3.1\%, to Mexico at $-3.0 \%$, and to Venezuela at $-6.3 \%$. [See Watson et. al. (1986), Table 10.] Over this same period, the interest rates on these loans were in the neighborhood of $12 \%$; hence the banks were receiving net payments.

It would appear quite feasible to extend the model developed here in several dimensions, in part making use of the growing literature on bargaining theory. We have already discussed the possibility of relaxing the risk-neutrality assumption. Also, some of our results may be sensitive to the assumed information structure. For example, a strong policy conclusion of our analysis is that the U.S. as a whole would be better off if its government could find a way to avoid bargaining with the banks and the country. (This is not necessarily possible, as we showed in Section V.) The point is that the banks and the country will achieve an efficient bargain without U.S. help, and an efficient bargain implies that there will be no suspension of trade with the U.S.. However, if the country has private information about its economy or political situation, then a bargain between the banks and the country may be reached only after some delay. ${ }^{33}$ In this case, there might be a role for a third party such as the International Monetary Fund (though the role might simply be to convey information). There are also some empirical puzzles which our model only partly resolves. Why, for example, did LDC borrowers pay such low risk premia during the seventies? ${ }^{34}$ Anticipated sidepayments from the U.S. may have been one factor, and one might argue that the severe adverse movements in LDC's terms of trade and in world interest rates were largely unanticipated events. Nevertheless, the risk premium puzzle merits further investigation.

33 Most models of bargaining with private information conclude either that not all efficient bargains will take place or that bargaining will involve costly delay. However, there are examples where this is not the case; see Gul and Sonnenschein (1985).

${ }^{34}$ See Folkerts-Landau (1985) or Edwards (1986). 


\section{References}

Brau, E., and Williams, R., "Recent Multilateral Debt Restructurings with Official and Bank Creditors," International Monetary Fund Occasional Paper no. 25, December 1983.

Cohen, Daniel, and Sachs, Jeffrey, "Growth and External Debt Under Risk of Debt Repudiation," European Economic Review, June 1986, 30, 529-560.

Cuddington, John T., and Smith, Gordon W., International Debt and the Developing Countries, 1985 (The World Bank: Washington, D.C.).

Dixit, Avinash, "Issues of Strategic Trade Policy for Small Countries," mimeo, Princeton University, 1986.

Eaton, Jonathan, and Gersovitz, Mark, "Debt with Potential Repudiation," Review of Economic Studies, April 1981, 48, 289-309.

Eaton, Jonathan, Gersovitz, Mark, and Stiglitz, Joseph E., “The Pure Theory of Country Risk," European Economic Review, June 1986, 30, 481-513.

Edwards, Sebastian, "The Pricing of Bonds and Bank Loans in International Markets: An Empirical Analysis of Developing Countries' Foreign Borrowing," European Economic Review, June 1986, 30, 565-589.

Folkerts-Landau, David F. J., "The Changing Role of Bank Lending in Development Finance," International Monetary Fund Staff Papers, June 1985, 32, 317-363.

Gul, Faruk, and Sonnenschein, Hugo, "Bargaining with One-Sided Uncertainty," working paper, Princeton University, 1985.

Kaletsky, Anatole, The Costs of Default, 1985 (Priority Press: New York).

Kyle, Steven, and Sachs, Jeffrey, "Developing Country Debt and the Market Value of Large Commercial Banks," National Bureau of Economic Research Working Paper no. 1470, September 1984.

Ozler, Sule, "Rescheduling of Sovereign Government Bank Loans," mimeo, November 1984, Stanford University. 
Rubinstein, Ariel, "Perfect Equilibrium in a Bargaining Model," Econometrica, January 1982, 50, 97-109.

Sachs, Jeffrey, "Theoretical Issues in International Borrowing," Princeton Studies in International Finance, 1984, 54 (Princeton, NJ).

Shaked, Avner, and Sutton, John, "Involuntary Unemployment as a Perfect Equilibrium in a Bargaining Model," Econometrica, November 1984, 52, 1351-1368.

Sutton, John, "Non-Cooperative Bargaining Theory: An Introduction," Review of Economic Studies, October 1986, 53, 709-724.

Watson, Maxwell; Mathieson, Donald; Kincaid, Russell; and Kalter, Eliot, "International Capital Markets: Developments and Prospects," International Monetary Fund Occasional Paper no. 43, February 1986.

World Bank, World Bank Debt Tables, 1985-86 edition (Washington, D.C.). 


\section{APPENDIX \\ TEN MAJOR LDC DEBTORS(a)}

Average Annual Percent

Total External Liabilities, 1985 (b) Exports $(c)$ Trade Balance Growth Rates

\begin{tabular}{|c|c|c|c|c|c|c|c|}
\hline & \multicolumn{2}{|c|}{ Total External Liabilities, $1985^{(b)}$} & \multirow{2}{*}{$\begin{array}{c}\text { Debt/GNP } \\
\text { ratio } \\
\end{array}$} & \multirow{2}{*}{$\begin{array}{c}\text { Exports }(c) \\
(\$ \text { Bill. }) \\
(1984)\end{array}$} & \multirow{2}{*}{$\begin{array}{c}\text { Trade Balance } \\
\qquad(\$ \text { Bill. }) \\
(1984) \\
\end{array}$} & \multicolumn{2}{|c|}{$\begin{array}{l}\text { Growth Rates } \\
(1980-1984) \\
\end{array}$} \\
\hline & (U.S. \$ Bill.) & Sources (percent) & & & & GDP & Exports $(d)$ \\
\hline Argentina & 50.8 & 86.8 & 71.9 & 8.1 & 4.0 & -1.4 & -5.4 \\
\hline Brazil & 107.3 & 84.2 & 49.7 & 27.0 & 13.1 & 0.1 & 1.6 \\
\hline Chile & 21.0 & 87.2 & 126.9 & 3.6 & 0.3 & -1.1 & -11.4 \\
\hline Colombia & 11.3 & 57.5 & 36.8 & 4.3 & 0.3 & 2.0 & -4.0 \\
\hline Mexico & 99.0 & 89.1 & 60.9 & 24.0 & 12.8 & 1.3 & 4.4 \\
\hline Morocco & 14.0 & 39.1 & 111.4 & 2.2 & -1.4 & 1.3 & -8.2 \\
\hline Nigeria & 19.3 & 88.2 & 22.9 & 11.8 & 3.0 & -4.3 & -22.3 \\
\hline Peru & 13.4 & 60.7 & 97.9 & 3.2 & 1.0 & -1.0 & -10.5 \\
\hline Phillipines & 24.8 & 67.8 & 76.1 & 5.4 & -0.7 & -0.2 & -7.3 \\
\hline Venezuela & 33.6 & 99.5 & 73.3 & 15.9 & 8.7 & -1.7 & -9.3 \\
\hline
\end{tabular}

(a) Source: Total external liabilities and debt/GNP ratios are from 1985/86 World Bank Debt Tables, p. xxv. Other data are from September 1986 IMF Financial Statistics, lines 77aad, 77acd, 99a,p, and 99b,p.

(b) Includes all long and short-term debt: public and private guaranteed debt, non-guaranteed private debt, and IMF credit.

(c) Merchandise exports.

(d) Real export growth is measured in constant 1980 dollars using the U.S. GNP deflator, calculated from lines 99a and 99a.r, p. 512. Data for Morocco are for 1980-1983 only. 